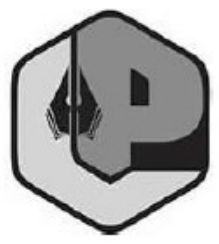

LINGUA PEDAGOGIA (Journal of English Teaching Studies)

Vol.1, No.2, September 2019

Online: https://journal.uny.ac.id/index.php/lingua-pedagogia/index

\title{
THE EFFECTS OF PARENTS' ATTENTION AND LEARNING DISCIPLINE ON THE ENGLISH LEARNING ACHIEVEMENT IN JUNIOR HIGH SCHOOLS
}

\author{
Sukhadman, Pujiati Suyata \\ SMP Negeri 3 Purwanegara Banjarnegara, Universitas Negeri Yogyakarta \\ Email: Sukhadman@ymail.com,pujiati_suyata@uny.ac.id
}

\begin{abstract}
This research aimed to desribe the effects of parents' attention and learning discipline on the English learning achievement and the correlation between parents' attention and learning discipline and the English learning achievement at grade $9^{\text {th }}$ in Junior High School. This research was an expost facto research. The population was 2.716 students. A sample of 337 students was established using the proportional stratified random sampling technique. The techniques of data collection were the questionnaries and the document of students' English learning achievement in the even of year 8 in $2012 / 2013$. The instrument valididty was assessed in terms of the content validity using Factor Analysis. The reliabilty of the instrument was assessed using Cronbach Alpha. The data were analyzed using the Multiple Regression and partial correlation analysis. Multiple Regression test results show that parents' attention and learning discipline simultaneously affect the English learning achivement with the value of $F=43.311$ and $p \leq 0.05$. Adjusted $\mathrm{R}^{2}$ value $=0.197$ means that the variant of the English learning achivement variable could be predicted by parents' attention and learning discipline $19.7 \%$. Meanwhile, according to the partial correlation analysis, parents' attention correlates with English learning achievement $(\mathrm{r}=0.385$ and $\mathrm{p} \leq 0.05)$. Learning discipline correlates with the English learning achievement $(\mathrm{r}=0.182$ and $\mathrm{p} \leq 0.05)$.
\end{abstract}

Keywords: parents' attention, learning discipline, and English learning achievement 


\section{Introduction}

English lesson at Junior High School level gets an important attention from the government. It can be proven that the English lesson is one of the lessons tested in the national exam among math, science, and Indonesian language. It is also based on competence based curriculum, the number of hours of English language support lessons for Junior High School students per week comprised 4 hours of lessons. Nevertheless, some schools even add the hours to 5 to 6 hours per week. This shows that learning English is very important. However, the attention given by the government has not been understood yet by the students.

High expectation of learning achievement is given by parents and teachers to the English learning process. The results of a process of learning for three years showed unsatisfied. The national exam result data showed that English placed the last ranks among four lessons in Banjarnegara regency at 2012. The average score of national exam in English lesson at Banjarnegara was 4,98. While the average of the others were Indonesia 8.14, math 5.37, and science 6.03. Meanwhile according to Standard Operational Procedure (2013, p.38) in Conducting national exam in Junior High School level, states that the students will graduate, if they have the average score 5.5. It can be concluded that the national exams result show that the English learning achievement is low.

The success of the English learning achievement has been influenced commonly by some factors. There are two factors influencing learning; internal and external factors. The Internal factors are the factor from the students while the external factors is the factor from outside the students such as family, school , and society (Sugihartono, et al., 2007, p.76). In other word, The English learning can be influenced not only from the students' factors but also the other factors from family who firstly gives the education, environment where the child grows. This factor can be predicted influencing the English learning achievement.

The success of English learning achievement has been influenced commonly by some factors. There are two factors influencing learning; internal and external factors. Internal factors are the factor from the students while the external factors is the factor from outside the students such as family, school ,and society (Sugihartono, et.al. 2007, p.76). In other word, English learning can be influenced not only from the students' factors but also the various factors from family who firstly gives the education, environment where the child grows. This factor can be predicted influencing English learning achievement.

Education for the children is firstly introduced in the family life. Being the venue of a family, parents play an important role in social and cognitive development of their children by placing high expectation to them. They try hard to meet their children's needs throughout the process of learning. From the preliminary observation, many parents had not given yet the children equipments supporting English learning, such as the English lesson book, dictionary, and reference English book. Meanwhile, a lot of students have been lent English lesson book and dictionary by the school.

Parents also have role and responsibility to nurture and educate their children in forming habits of learning. One of the responsibilities is paying attention to the children in learning English. Parents' responsibility in paying attention to their children relate to their educational background. The school data show that a lot of parents do not have the formal education background. The students' parents are commonly graduated from the elementary school or junior high school. It means that parents have low education.

According to the preliminary interview to some students, parents have not given enough attention yet to their children in learning English at home. They rarely help, guide, and check the English homework. They seldom 
give motivation, and discuss the problem faced by the children in learning English. Meanwhile, knowledge how to pay attention to children in learning is only learnt from what they got from their parents. Meanwhile parents who have a high background of education, junior high school level or up, usually give more attention to their children. Teaching given to children whose parents are not in accordance with the current conditions will be abandoned or adjusted. Parents of these differences will make a difference in the attention given to their children. Educational parents can better communicate with their children regarding the school works, activities and the information being taught at school. They can better assist their children in their work and participate at school. Von Secker (2004) in Epstein (2009, p.48) showed that parents education and measures of the home environment helped compensate for low science achievement associated with lower family and minority status.

The other matter is parents can not help, guiding and checking the children homework because of the low education. They do not have enough knowledge to help their children's problem in learning English. According to Von Secker (2004) in Epstein (2009, p.48) states "that is, low income and minority students had higher science scores if their parents had more formal education and encouraged their education at home. It can be concluded that the students from the family that have a formal education had higher score.

Family background in Banjarnegara regency is highly heterogeneous because Banjarnegara district areas are mountainous in the east, north and south, while the west is an area of rice fields. Such differences include educational background, occupation, social status, and political. The main livelihoods are farmers and traders. So, the time in which parents have to communicate or discuss about the progress and the problem faced by their children in learning English is limited. So, they do not know much about the children progress in learning English.
In the modern educational plans, the main purpose of English learning discipline is to create the educational environment and opportunities for English learning process. Indeed, discipline is an instrument for realizing the high educational goals that leads to the students' growth and progress in every dimension. Gaining the educational goal is needed the self- control and the responsibility of students by caring teacher or parents. Savage and Savage (2010, p.8) states "Developing of self-control and the acceptance of responsibility are outcomes that are facilitated by caring teachers interacting with students in way that help them understand the consequences of their choices". The student factors are also the other factor influencing the English learning. One of those factors is learning discipline. Learning discipline is one of the most effective factors in English teaching learning process.

The student behavior problems have been a major concern for teachers, administrators and parents. More than ever before, based on teachers' information, teacher are faced to critical problems in English learning process at their classrooms, and are confronted (on a daily basis) with unacceptable students behavior or misbehave and threatening situations. Those are the effect of the use of punishment at home and the school considered as the place to build the character. Unacceptable students behavior or misbehave and threatening situations will make the uncomfortable school climate for English learning. Flicker and Hoffman (2006, p.2) state "in early 1900 s there was a continuation of the use of punishment at home and in school to build character".

The emergence of learning discipline does not occur suddenly but there are the needs of the refraction. Learning discipline in English lesson requires the process and the exercises that is quite long and continuous. Introduction and implanting of English learning discipline to children can be done at home and at school. Applying English learning discipline in the home should be 
initiated at the early age by giving habits and a good example of behavior to children. This is because habit is instilled and the example shown by the parents will be borne by the child and affect future behavior towards child discipline. Flicker and Hoffman (2006, p.9) states children' individual differences in learning and development are based on the familial and cultural experiences that require adults to adapt their discipline strategies to meet the unique needs.

Further Flicker and Hoffman (2006, p.9) state "developing in discipline is based on the conviction that learning rules for behavior is a dynamic and constant process that begin in infancy from parents and teachers". So, learning discipline is a process of the learning implanted at the early age at home. In fact, from the preliminary observation in the classroom, learning discipline in English lesson has not been implanted by parents yet at home. The children did not have enough responsibility in English learning equipments and learning activity according to the homework or reading the material after the school. It can be seen from the students' preparation in learning English. Most of the students had not yet studied or did the homework before the class begins, while the equipments were not completed.

Schools also have an important task to teach children to differentiate between acceptable and unacceptable behavior in the English learning process. Opportunity must be given for the development of insight and learning. In a positive school climate, breaking of school rules is therefore viewed as not only a negative action towards the school, but also a negative action towards fellow students, teachers and the disruption of mutual relationships. The school rules are the instrument $\mathrm{n}$ creating a positive school climate.

The important of learning discipline can be predicted to improve the English learning achievement followed the rules that is stated together (school, parents, and learners) in order to the classroom of the English learning and teaching process to gain the high expectation in the English learning achievement. The children who have a high learning discipline can accomplish school works well, such as learning regularly at home, reading related textbooks, and doing the school works on time. Whereas children who have less learning discipline at school will allowed low academic achievement. Based the information from the teachers, headmasters, and staffs, the students have not yet shown the high learning discipline in the English learning process at school. It is likely as a cause of the low of English learning achievement.

The problems of this study are as follows. How is a correlation between parents' attention and the English learning achievement in Junior High Schools at Regional Coordination 3rd in Banjarnegara regency?. How is a correlation between learning discipline and the English learning achievement in Junior High Schools at Regional Coordination 3rd in Banjarnegara regency?. What are the effects of parents' attention and learning discipline on the English learning achievement in Junior High Schools at Regional Coordination 3rd in Banjarnegara regency?.

Meanwhile, The objectives of this research are to investigate a correlation between of parents' attention and the English learning achievement in Junior High Schools at Regional Coordination 3rd in Banjarnegara regency, to investigate a correlation between learning discipline and the English learning achievement in Junior High Schools at Regional Coordination 3rd in Banjarnegara regency, and to investigate the effects of parents' attention and learning discipline on the English learning achievement in Junior High Schools at Regional Coordination 3rd in Banjarnegara regency.

Hopefully, this research can provide a reference for Teachers to improve the discipline for the students in learning English at school. This research also helps the teachers to create the good climate in the class for students in learning English. The other 
benefits of this research for the teachers are to guide or implant the students discipline in learning English at school or at home. This research also provides the information to the parents how importance of parents' attention to their children in supporting the children in learning English. So, parents can help their children to achieve the English learning achievement and make a good climate for their children in learning English. For policy makers, this research is expected to give contribution and the ideas for them of improvement or revamping the learning system at school. So the learning teaching process can happen in a good climate.

\section{Research Method}

\section{Research Design}

This research is a quantitative study, conducted using an ex post facto method. According Cohen, L et. al. (2005, p.206) cited from Kerlinger defines ex post facto research more formally as that in which the dependent variable or variables have already occurred and in which the researcher starts with the observation of dependent variable or variables

\section{Setting of Research}

The setting of this research was conducted in State Junior High Schools at Banjarnegara regency. Meanwhile, the research time was conducted from November to December 2013.

Population and Sampling of the Research

Population of this research was the students of $9^{\text {th }}$ grade of State Junior High School in Regional Coordination $3^{\text {rd }}$ (KORDA 3) at Banjarnegara in the academic year of $2013 / 2014$. The population was only limited to the State Junior High School students because they had followed UN at the academic year of 2011/2012. The number of them were 16 Junior High Schools. The population was amounted 2.716 learners spreading in 16 Junior High Schools. The technique of taking sample used proportional stratified random sampling technique. Determining the sample size, the researcher uses Isaac and Michel (1981:192) formula, for the population 2.716. the number of sample size was 337 students.

Taking the representative sample, the population was divided into three levels according to the National Exam from academic year of 2011/2012. The result of National Exam distribution for the high level with the score $\geq 5.50$ was 2 schools, for the medium level (4.50-5.49) 8 schools, and for the low level (3.50-4.49) 6 schools. The students from high level was taken 62 students. The students from the madium level was taken 200 students. The students from the low level was taken 75 students.

Data, instrument, and Data Collecting Technique

The variables in this research are divided into two variables: dependent variable and independent variables. The dependent variable is the English learning achievement. The independent variables are parents' attention and learning discipline.

This research used two techniques in the data collecting. They are questionnaires and the final semester test score of the even $8^{\text {th }}$ grade in English lesson from academic year of 2012/2013 as the English learning achievemen of Junior High School students in Banjarnegara.Questionnaire was used to collect data from the predicted variable that influences English learning achievement in Banjarnegara. Likert scale is used in this research to measure those aspects.

The questionnaires used for parents' attention and learning discipline was checklist form. They consists of the questions about parents' attention and learning discipline to the English learning. they use the Likert scale that was equipped by four choices answers. Those are always, often, rarely, and never. 
A research instrument, either in the form of questionnaires (non-test) was said to have high validity if it measured targets that should be measured. This meant that the validity of an instrument was the most important characteristic. For the non test instrument validity as questionnaire used to collect data should fulfill the construct validity. This type of validity was a judgment based on the accumulation of evidence from numerous studies using a specific measuring instrument. Evaluation of construct validity requires examining the relationship of the measure being evaluated with variables known to be related or theoretically related to the construct measured by the instrument.

The validity for questionnaire instrument used construct validity consulting the indicators used in this instrument by expert judgment.

After consulting to the expert judgment, and getting the agreement, the instruments were tried to 46 students who had the equal ability of the sample. The students as the respondents were the students of grade IX A and IX D State Junior High School 3 of Purwanegara. The construct validity test of this study was conducted by factor analysis using SPSS version 17.00 for windows, then, it was analyzed to determine grain instrument valid and invalid items.

Factor analysis required data matrix that must have a sufficient correlation factor analysis to be performed. Statistical test was used to determine whether there was any correlation between the variables used. Prior to the extraction of the factors, several tests should be used to assess the suitability of the respondent data for factor analysis. These tests include Kaiser-Meyer-Olkin (KMO) Measure of Sampling Adequacy, and Bartlett's Test of Sphericity. The KMO index, in particular, was recommended when the cases to variable ratio were less than 1:5. The KMO index ranges from 0 to 1 , with 0.50 considered suitable for factor analysis. The Bartlett's Test of Sphericity should be significant $(p<.05)$ for factor analysis to be suitable.
Instrument reliability related to the stability and consistency of the instrument. Stability in the sense of an instrument used to measure the same object, would yield the same data or consistent.

Calculating the reliability coefficient used SPSS version 17.0 for windows to Cronbach Apha. The reliability coefficient assessed the consistency of the entire scale, with Cronbach Apha being the most widely used measure. Hair et.al., (2006, P. 137) states the generally agreed lower limit for Cronbach Apha is 0.70 .

Technique of Data Analysis

This research used multiple regression and partial correlation statistics in analyzing the data. Before having multiple regressions, the data must pass the pre analysis tests. The pre analysis tests were normality test, linearity test, multicoloniearity test, and heteroscedaticty. The description of pre analysis test was presented as follows.

\section{Normality Test}

The normality test was calculated using SPSS 17.00 for windows. The normality test used to examine the data of parents' attention, learning discipline and English learning achievement came from a normal distribution population or not. The analyzing normality data used One-Sample Kolmogorov Smirnov test at significance level of 0.05 . The data was asserted the normal distribution, if the significance of all variables were $p \geq 0,05$.

Table 22 Data Normality Test Result of Kolmogorov-Smirnov

\begin{tabular}{cccc}
\hline \hline & $\mathrm{X} 1$ & $\mathrm{X} 2$ & $\mathrm{Y}$ \\
& Parent & Learni & English \\
s' & ng & learning \\
& $\begin{array}{c}\text { Attent } \\
\text { ion }\end{array}$ & $\begin{array}{c}\text { Discip } \\
\text { line }\end{array}$ & $\begin{array}{c}\text { achieve } \\
\text { ment }\end{array}$ \\
\hline $\mathrm{N}$ & 337 & 337 & 337
\end{tabular}




\begin{tabular}{|c|c|c|c|c|}
\hline $\begin{array}{l}\text { Norm } \\
\text { al }\end{array}$ & Mean & $\begin{array}{r}77.393 \\
2\end{array}$ & 85.99 & 59.8181 \\
\hline $\begin{array}{l}\text { Param } \\
\text { eters(a } \\
\text { h) }\end{array}$ & $\begin{array}{l}\text { Std. } \\
\text { Deviat }\end{array}$ & $\begin{array}{r}11.287 \\
59\end{array}$ & 8.682 & $\begin{array}{r}13.9269 \\
5\end{array}$ \\
\hline $\begin{array}{l}\text { Most } \\
\text { Extre }\end{array}$ & $\begin{array}{l}\text { Absol } \\
\text { ute }\end{array}$ & .053 & .056 & .051 \\
\hline & $\begin{array}{l}\text { Positi } \\
\text { ve }\end{array}$ & .035 & .056 & .047 \\
\hline ences & $\begin{array}{l}\text { Negati } \\
\text { ve }\end{array}$ & -.053 & -.046 & -.051 \\
\hline \multirow{2}{*}{\multicolumn{2}{|c|}{$\begin{array}{l}\text { Kolmogorov- } \\
\text { Smirnov Z } \\
\text { Asymp. Sig. } \\
\text { (2-tailed) }\end{array}$}} & .968 & 1.020 & .930 \\
\hline & & .306 & .249 & .353 \\
\hline
\end{tabular}

The significance value for the each variable was $p=0.306$ for parents' attention, $p$ $=0.249$ for learning discipline, and $p=0.353$ for English learning achievement. The value for two independent variables and one dependent variable were above more than 0.05 $(\geq 0.05)$. It was concluded that the data for all variables distributed normally.

Based on the histogram of normal Q-Q plot above showed that the line represented the actual data distribution closely follow the diagonal. It was concluded that the data distribution was normal.

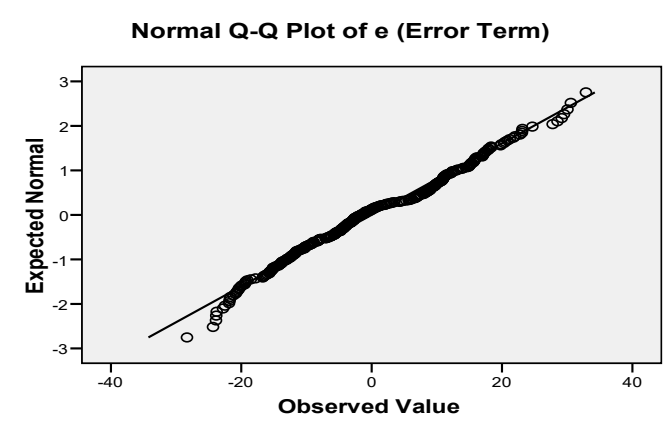

Figure 8 Normal Q-Q Plot

\section{Linearity Test}

Linearity test was conducted one by one between dependent variable and independent variables. Showing the linearity of parents attention and English learning achievement was used SPSS 17.00 for windows. Based on the table 19, Sig.deviation from linearity of parents' attention was 0.88 . It was above 0.05 $(\geq 0,05) . \quad$ It was concluded that the relationship between parents' attention and English learning achievement was linier.

Table 23 Linearity Test of Parents' Attention

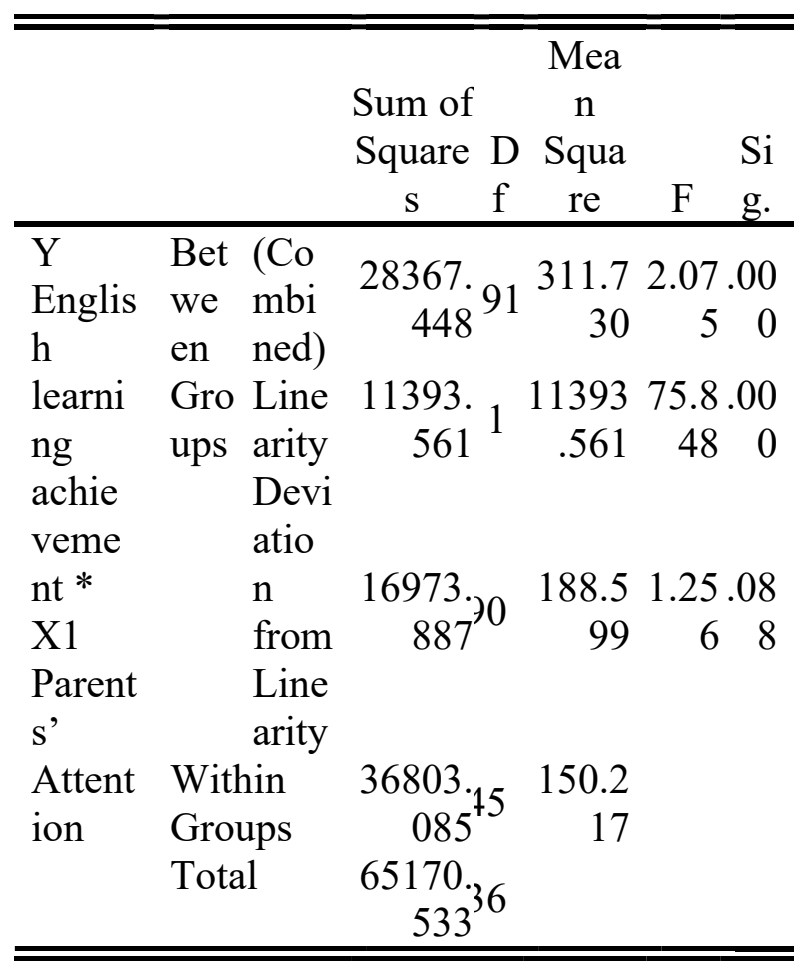

Based on the table above, it showed that Sign.deviation from linearity of learning discipline was 0.553 . It meant that the Sign.deviation from linearity of learning discipline was $0.553 \geq 0.05$. It was concluded that the relationship between learning discipline and English learning achievement was linier.

Table 24 The linearity Test of Learning Discipline

Sum D Mea F Sig 


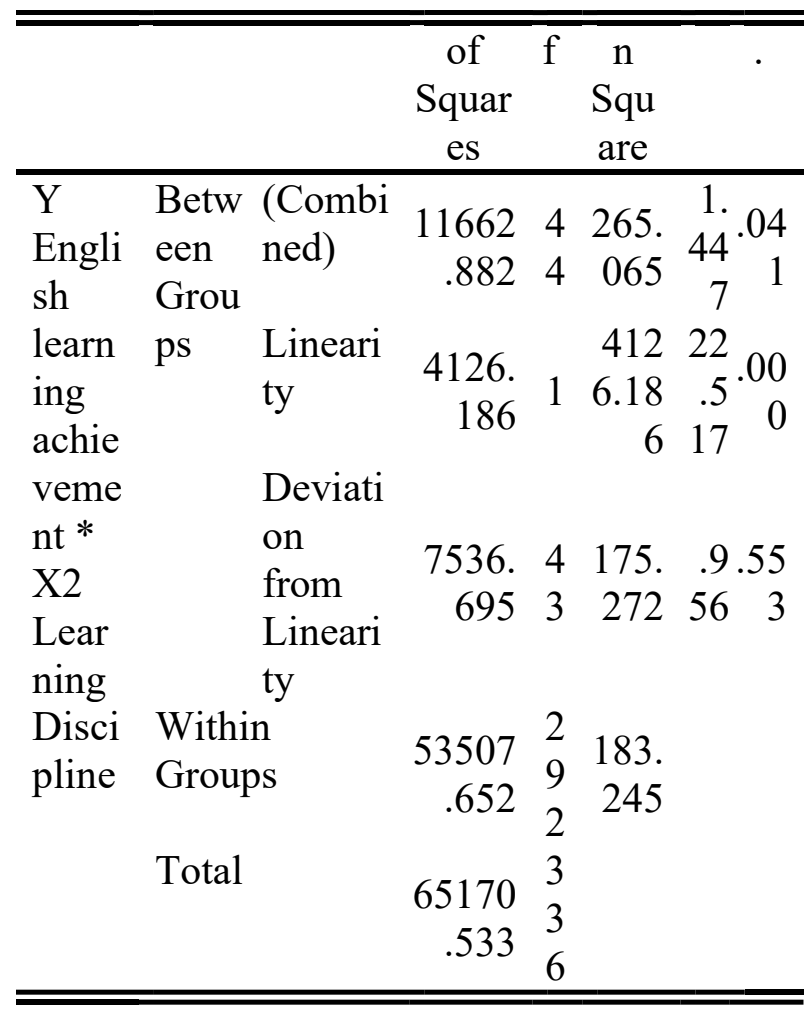

Multicollinearity Test

Multicollinearity test is aimed to test what Multiple Regression found the correlation between independent variables. Detecting multicollinearity in Multiple Regression model saw the tolerance value and Variance Inflation Factor (VIF) value. If the VIF value not more than $0.10(\geq 0,10)$ and tolerance value not less than $0.10(\leq 0.10)$ were concluded that the regression model was free from multicollinearity. Determining the value of VIF and Tolerance used SPSS program version 17.00 for windows.

Table 25 Tolerance and VIF Value

\begin{tabular}{|c|c|c|c|c|}
\hline & $\begin{array}{c}\text { Unstan } \\
\text { dardize } \\
\mathrm{d} \\
\text { Coeffic } \\
\text { ients }\end{array}$ & $\begin{array}{l}\text { Standa } \\
\text { rdized } \\
\text { Coeffi } \\
\text { cients }\end{array}$ & t Sig. & $\begin{array}{c}\text { Collinea } \\
\text { rity } \\
\text { Statistic } \\
\text { s }\end{array}$ \\
\hline$M$ & \multicolumn{2}{|c|}{ Std } & \multicolumn{2}{|r|}{$\begin{array}{l}\text { Tol } \\
\text { eran }\end{array}$} \\
\hline del & B $\mathrm{Er}$ & - Beta & & ce VIF \\
\hline
\end{tabular}

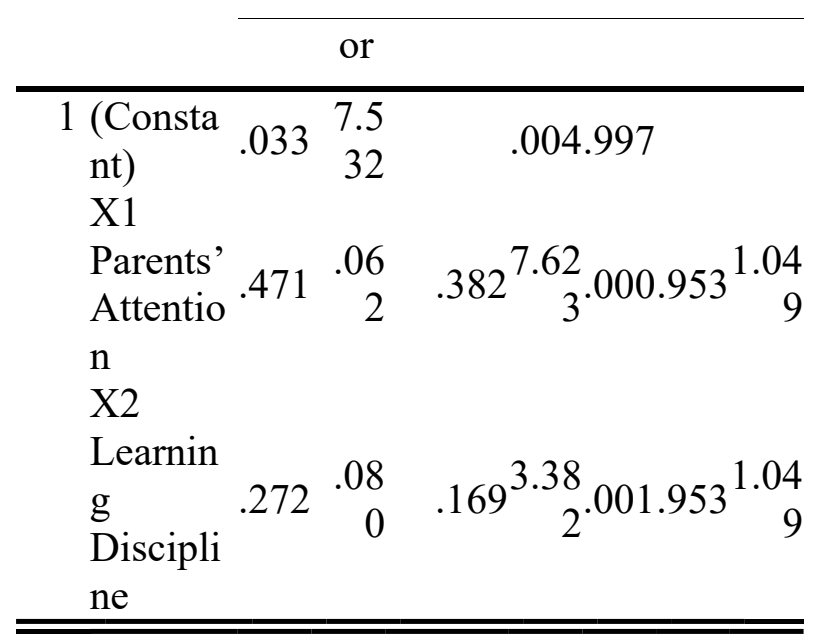

a Dependent Variable: Y English learning achievement

Based on the table above, Tolerance value from parents attention 0.953 and learning discipline 0.953 showed both independent variables didn't have Tolerance value under $0.10(<0.10)$. The computation result of VIF value from parents attention 1.049 and learning discipline 1.049 showed both independent variables didn't have VIF value more that $0.10(>0.10)$. It meant that there was no multicollinearity between independent variables in regression model.

\section{Heteroscedasticity Test}

Heteroscedasticity was determined by the scatterplot. If the data points spread on and under 0 score at $\mathrm{Y}$ axle, it was concluded that there was no heteroscedasticity.

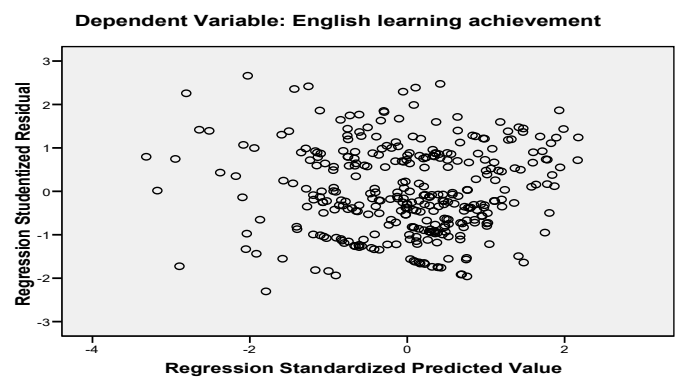

Figure 9 Distribution of Residual Variable 
From scatterplot above, the data points spread randomly on or under 0 score at $\mathrm{Y}$ axle, it was concluded that there was no heteroscedasticity.

The statistic test used to detect heteroscedasticity by Glejser test was by helping SPSS 17.00 for windows. Based on Table 26, the significance of parents' attention was 0.128 . It meant that the significance value of parents' attention was $0.128 \geq 0.05$. It was concluded that there was not heteroscedasticity in the regression model.

Table 26 Glejser Test of Parents' Attention

\begin{tabular}{|c|c|c|c|c|}
\hline \multirow{3}{*}{$\begin{array}{l}\text { Mod } \\
\text { el }\end{array}$} & & \multicolumn{2}{|c|}{$\begin{array}{l}\text { Unstandar Standar } \\
\text { dized dized } \\
\text { Coefficien1Coeffici }\end{array}$} & \multirow{3}{*}{ Sig } \\
\hline & & $\begin{array}{c}\text { Std } \\
\text { Err }\end{array}$ & & \\
\hline & & $\mathrm{B}$ or & Beta & \\
\hline$\overline{1}$ & $\begin{array}{l}\text { (Constant } \\
\text { ) } \\
\text { X1 } \\
\text { Parents' } \\
\text { Attention }\end{array}$ & $\begin{array}{r}14.26)^{2.5} \\
9 \varepsilon \\
-.051 .0 z \\
\vdots\end{array}$ & -.08 & $\begin{array}{rr}5.49 & .00 \\
2 & 0 \\
- & \\
1.52 & .12 \\
6 & 8 \\
\end{array}$ \\
\hline
\end{tabular}

Based on Table 27 below, the significance of learning discipline was 0.128. It meant that the significance value of learning discipline was $0.128 \geq 0.05$. It was concluded that there is not heteroscedasticity in the regression model.

Table 27 Glejser Test of Learning Discipline

\begin{tabular}{|c|c|c|c|c|}
\hline \multirow{3}{*}{$\begin{array}{l}\text { Mo } \\
\text { del }\end{array}$} & $\begin{array}{c}\text { Unstandar } \\
\text { dized } \\
\text { Coefficient }\end{array}$ & $\begin{array}{l}\text { Standar } \\
\text { dized } \\
\text { Coeffici }\end{array}$ & \multirow[b]{3}{*}{$\mathrm{t}$} & \multirow[b]{3}{*}{ Sig. } \\
\hline & $\mathrm{S}$ & ents & & \\
\hline & Std. & Beta & & \\
\hline
\end{tabular}

\begin{tabular}{lrrrrr}
\hline 1 (Consta & 14.8 & 3.73 & & 3.9 & .000 \\
$\mathrm{nt})$ & 38 & 7 & & 71 & \\
$\mathrm{X} 2$ & & & & & \\
Learnin & & & & - & \\
$\mathrm{g}$ & -.052 & .043 & -.066 & 1.2 & .228 \\
Discipli & & & & 09 & \\
ne & & & & & \\
\hline \hline
\end{tabular}

\section{Finding and Discussion}

The description of the research result was obtained from the questionnaires that were given to 337 students and English learning achievement documents. English achievement document was obtained from the final semester test at 8 th grade in academic year of 2012/2013. The data presented in the form of raw data was processed using statistical description technique. The descriptive research result was presented in the form of the mean, median, mode, standard deviation, minimum and maximal score of each variable in this research.

For the interval score interpretation from the lowest to the highest score was divided into four categories: high, enough high, enough low and low. The way to make the interval score for each category of levels was the highest score - the lowest score divided by four categories.

English Learning Achievement

Based on the results of statistical analysis, the variable data of the English learning achievement of Junior High School students selected as samples had scores range 2.25 to 9.50. English learning achievement scores were obtained from the final semester test at $8^{\text {th }}$ grade in State Junior High Schools. The results of the data analysis of English learning achievement used the helping of SPSS 17.0 for windows. According to the results of data analysis showed that the 
English learning achievement of Junior High School students had mean 59.8181, median 60.0000 , mode 60.00 , standard deviation 13.92695, minimum 20.25 and maximum score 95.0. The frequency distribution of English learning achievement scores is presented in the following table.

Table 16 Frequency Distribution of English Learning Achievement

\begin{tabular}{lll}
\hline No & \multicolumn{1}{c}{ Parametric } & \multicolumn{1}{c}{ Score } \\
\hline 1 & Mean & 59.8181 \\
2 & Median & 60.000 \\
3 & Mode & 60.00 \\
4 & Standard. Deviation & 13.92695 \\
5 & Minimum & 20.25 \\
6 & Maximum & 95.00 \\
\hline
\end{tabular}

The criterion of mastery learning (KKM) is 70. The statistics data showed that English learning achievement $<$ KKM $(<70)$ was $72.11 \%$, while students who had equal or greater value than the criterion of mastery learning $\geq \mathrm{KKM}(\geq 70)$ was $27.9 \%$. The score distribution of English learning achievement based on the KKM 70 at Junior High School Students as the following.

Table 17 Score Distribution of English Learning Achievement

\begin{tabular}{llcc}
\hline \multicolumn{1}{c}{ Category } & \multicolumn{1}{c}{$\begin{array}{c}\text { Score } \\
\text { Interval }\end{array}$} & $\begin{array}{c}\text { Frequenc } \\
\mathrm{y}\end{array}$ & $\begin{array}{c}\text { Percen } \\
\mathrm{t}\end{array}$ \\
\hline $\begin{array}{l}\text { Above } \\
\text { equal KKM }\end{array}$ & $\begin{array}{l}=>\mathrm{KKM} \\
(=>\mathrm{KKM}\end{array}$ & 243 & 72.11 \\
Below KKM & $\begin{array}{l}70) \\
<\mathrm{KKM} \\
(<70)\end{array}$ & 94 & 27.89 \\
& & \\
\hline
\end{tabular}

The score distribution of English learning achievement could also be shown by the following histogram.

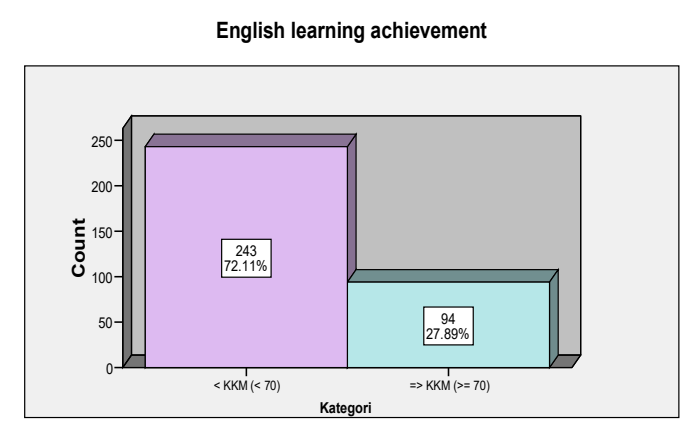

Figure 5 Score Distribution of English Learning Achievement

Based on the histogram above, it showed that Junior High School students getting the score up or equal of the criterion of mastery learning $(\mathrm{KKM}) \geq 70$ were 94 students. It meant that $27.89 \%$ students from 337 samples in this research got through KKM that was determined by the school. Meanwhile, the Junior High School students getting the score under the criterion of mastery learning (KKM) $<70$ were 243 students. It meant that $72.11 \%$ students from 337 samples in this research got under KKM that was determined by the school.

Parents' Attention

The statistical analysis result, the independent variable (parents' attention) had particularly range score 27 to 108 and mean 81. The interval categories in four group delivered 20.25. The score of parents' attention was obtained from the students questionnaire scores. The analysis data result of parents' attention used helping SPSS 17.0 for windows.

The data analysis result showed that the parents' attention variable in Junior High School students had the score from 40.50 to 101, mean 77.3932, median 78.5000, mode 78.50, standard deviation11.28759, minimum 40.50 and maximum score 101. The score distribution of parents' attention is presented in the following table. 
Table 18 Frequency Distribution of Parents' Attention

\begin{tabular}{lll}
\hline No & \multicolumn{1}{c}{ Parametric } & \multicolumn{1}{c}{ Score } \\
\hline 1 & Mean & 77.3932 \\
2 & Median & 78.5000 \\
3 & Mode & 78.50 \\
4 & Standard. Deviation & 11.28759 \\
5 & Minimum & 40.50 \\
6 & Maximum & 101 \\
\hline
\end{tabular}

The frequency distribution of Junior High School students who gained the parents' attention was classified into four group: high $16.3 \%, 68.2 \%$ quite high, $14.5 \%$ quite low, and $9 \%$ low. Based on the above data, it could generally be concluded that the parents' attention of Junior High School students of grade IX in Banjarnegara regency included a high enough category. Its indication showed that the percentage of parents' attention to their children who learnt English was $68.2 \%$.

Table 19 Score Distribution of Parents' Attention

\begin{tabular}{|c|c|c|c|c|}
\hline $\begin{array}{c}\text { Catego } \\
\text { ries }\end{array}$ & $\begin{array}{l}\text { Interval } \\
\text { Limitation }\end{array}$ & $\begin{array}{l}\text { Scores } \\
\text { Range }\end{array}$ & $\begin{array}{c}\text { Frequen } \\
\text { cy }\end{array}$ & Percent \\
\hline High & $\begin{array}{l}\operatorname{Min}+3 \mathrm{Ct} \\
\operatorname{Min}+4 \mathrm{C}\end{array}$ & $\begin{array}{c}\text { to }>87.75- \\
108\end{array}$ & 55 & 16.3 \\
\hline $\begin{array}{l}\text { High } \\
\text { enough }\end{array}$ & $\begin{array}{l}\operatorname{Min}+2 C t \\
M i n+3 C\end{array}$ & $\begin{array}{c}\text { to }>67.50- \\
87.75\end{array}$ & 230 & 68.2 \\
\hline Quite & $\operatorname{Min}+\mathrm{C}$ & to $>47.25-$ & 49 & 14.5 \\
\hline Low & $\mathrm{Min}+2 \mathrm{C}$ & 67.50 & & \\
\hline Low & $\begin{array}{l}\operatorname{Min} t \\
\operatorname{Min}+C\end{array}$ & to $27-47.25$ & 3 & 9 \\
\hline
\end{tabular}

The score distribution of parents' attention was also shown by the following histogram.

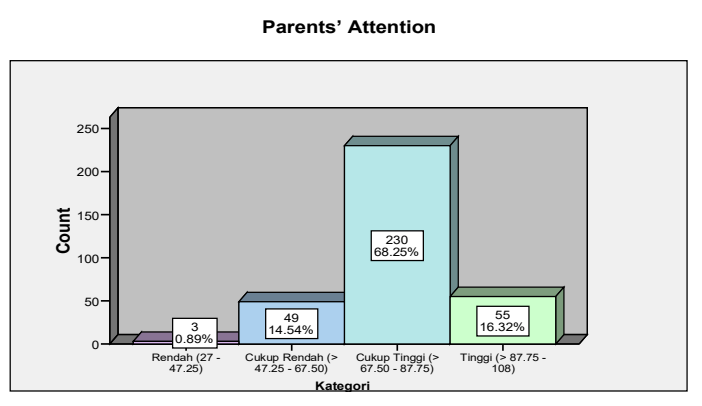

Figure 6 Score Distribution of Parents' Attention

The histogram above showed that the Junior High School students got parents' attention from their parents in English learning classified into four categories: high $6.3 \%$, quite high $68.2 \%$, quite low $14.5 \%$, and low $9 \%$. It meant that 55 students from 337 samples in this research gained the high parents' attention, 230 students from 337 samples in this research gained the quite high parents' attention, 49 students from 337 samples in this research gained the quite low parents' attention, and 3 students from 337 samples in this research gained the low parents attention.

\section{Learning Discipline}

The statistical analysis result, the independent variable (learning discipline) had particularly range score 30 to 120 and mean 90. The interval categories in four group delivered 22.50. The score of parents' attention was obtained from the students questionnaire scores. The result of the learning discipline was analyzed using SPSS 17.0 for windows.

The learning discipline data analysis results showed that the learning discipline from Junior High School students had the score from 60 to 111, mean 85.99, median 85.0, mode 84, standard deviation 8.682, minimum 60, and maximum score 111 . The frequency distribution scores of learning discipline are presented in the following table. 
Table 20 Frequency Distribution of Learning Discipline

\begin{tabular}{lll}
\hline No & \multicolumn{1}{c}{ Parametric } & \multicolumn{1}{c}{ Score } \\
\hline 1 & Mean & 85.99 \\
2 & Median & 85.0 \\
3 & Mode & 84 \\
4 & Standard. Deviation & 8.682 \\
5 & Minimum & 60 \\
6 & Maximum & 111 \\
\hline
\end{tabular}

The frequency distribution of Junior High School students who had the learning discipline classified into four categories: high $8,3 \%$, quite high $80,7 \%$, and quite low $11 \%$. Based on the above data, it was concluded that the learning discipline of Junior High School students of grade IX in Banjarnegara regency had the enough high category. Its indication of the largest percentage was gained $80,7 \%$.

Table 21 Score Distribution of Learning Discipline

\begin{tabular}{|c|c|c|c|c|}
\hline Categorie & Interval & Scores & Frequ & Perce \\
\hline $\mathrm{s}$ & Limitation & Range & ncy & $\mathrm{nt}$ \\
\hline High & $\mathrm{Min}+3 \mathrm{C}$ & to $>97.50$ & 28 & 8.3 \\
\hline & $\operatorname{Min}+4 \mathrm{C}$ & 120 & & \\
\hline Enough & $\mathrm{Min}+2 \mathrm{C}$ & to $>75-$ & 272 & 80,7 \\
\hline high & $\mathrm{Min}+3 \mathrm{C}$ & 97.50 & & \\
\hline Enough & $\operatorname{Min}+\mathrm{C}$ & to $>52.50$ & 37 & 11 \\
\hline low & $\mathrm{Min}+2 \mathrm{C}$ & 75 & & \\
\hline Low & Min to Min & $1+>30-$ & 0 & 0 \\
\hline & $\mathrm{C}$ & 52.50 & & \\
\hline
\end{tabular}

The score distribution of learning discipline is also shown by the following histogram.

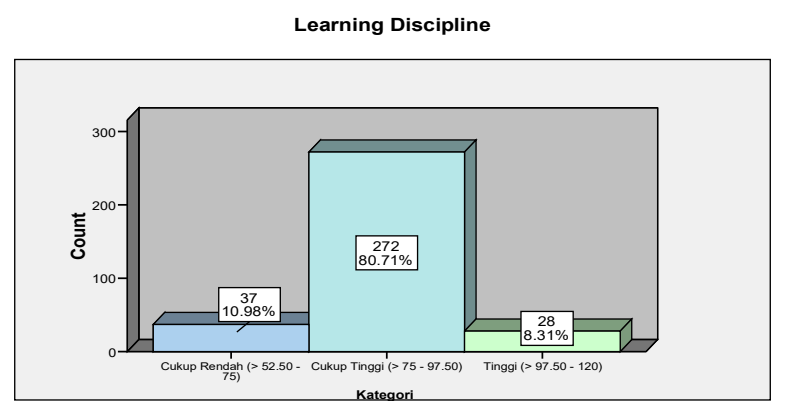

Figure 7 Score Distribution of Learning Discipline

The histogram above showed that the Junior High School students had learning discipline in English learning classified into four categories: high $8.3 \%$, quite high 80,7 $\%$, and enough low $11 \%$. It meant that 28 students from 337 samples in this research had the high learning discipline; 272 students from 337 samples in this research had the enough high learning discipline, 37 students from 337 samples in this research had the quite low learning discipline.

\section{Hypothesis Test}

This research had three hypothesis. The criteria for these hypothesis is Ho is rejected if $p \geq 0.05$ of significance level. The first and the second hypothesis were tested using partial correlation and the third hypothesis was tested using multiple regression. The detail hypothesis test is described as the following.

First Hypothesis Result

The output of partial correlation analysis result of parents' attention variable and the English learning achievement variable controlled by learning discipline was in which correlation coefficient ( $r$ ) was $r=0.385$ and $p$ $\leq 0.05$. So the decision of the second hypothesis $\mathrm{Ha}$ was accepted. The role of parents' attention had the coefficient $\beta$ value 0.382 . It is concluded that there is the correlation between parents' attention and the English learning achievement in Junior High Schools at Regional Coordination $3^{\text {rd }}$ in Banjarnegara regency.

Second Hypothesis Result

The output of partial correlation analysis result between learning discipline variable and the English learning achievement variable controlled by parents' attention was in which correlation coefficient (r) was $r=0.182$ and $p$ 
$\leq 0.05$. So the decision of the second hypothesis $\mathrm{Ha}$ was accepted. The role of learning discipline to English learning achievement had the coefficient $\beta$ value 0.169 . It is concluded that there is the correlation between learning discipline and English learning achievement in Junior High Schools at Regional Coordination $3^{\text {rd }}$ in Banjarnegara regency.

Third Hypothesis Result

According to Table 30, the output Multiple Regression described as the following.

Table 30 Output of Multiple Regression Test

\begin{tabular}{lrrrr}
\multicolumn{5}{c}{ Model Summary(b) } \\
\hline \hline & \multicolumn{4}{c}{ Adjuste } \\
$\begin{array}{l}\text { Mod } \\
\text { el }\end{array}$ & \multicolumn{2}{c}{$\begin{array}{c}\mathrm{R} \\
\mathrm{d} \text { R }\end{array}$} & $\begin{array}{c}\text { Std. Error of } \\
\text { Square }\end{array}$ & $\begin{array}{l}\text { Square } \\
\text { the Estimate }\end{array}$ \\
\hline 1 & $.450(\mathrm{a}$ & .202 & .197 & 12.47713 \\
\hline \hline
\end{tabular}

a Predictors: (Constant), X2 Learning Discipline, X1 Parents' Attention

b Dependent Variable: Y English learning achievement

ANOVA(b)

\begin{tabular}{|c|c|c|c|c|c|}
\hline $\begin{array}{l}\text { Mod } \\
\text { el }\end{array}$ & & $\begin{array}{l}\text { Sum of } \\
\text { Squares }\end{array}$ & $\begin{array}{r}\text { Mean } \\
\text { Df Square }\end{array}$ & $\mathrm{F}$ & Sig. \\
\hline \multirow[t]{2}{*}{1} & $\begin{array}{l}\text { Regr } \\
\text { essio }\end{array}$ & $\begin{array}{r}13173.81 \\
0\end{array}$ & $2 \begin{array}{r}6586.9 \\
05\end{array}$ & $\begin{array}{r}42.3 \\
11\end{array}$ & $\begin{array}{r}.000( \\
\mathrm{a})\end{array}$ \\
\hline & $\begin{array}{l}\text { Resi } \\
\text { dual } \\
\text { Total }\end{array}$ & $\begin{array}{r}51996.72 \\
3 \\
65170.53 \\
3\end{array}$ & $\begin{array}{r}34 \\
95.67 \\
36\end{array}$ & & \\
\hline
\end{tabular}

a Predictors: (Constant), X2 Learning Discipline, X1 Parents' Attention

b Dependent Variable: Y English learning achievement

Regression analysis with SPSS version 17.0 for windows, was found the value of determination coefficient (Adjusted R Square) 0.197 . It was interpreted that the variant of English learning achievement of junior high school students in Banjarnegara regency was predicted by parents' attention and learning discipline variable $19.7 \%$. Remaining value $100 \%-19.7 \%=80.3 \%$ were predicted by other variables not examined in this research.

The value of $F$ is 42.31 and $p \leq 0.05$. The results of these calculations was used to conclude that parents' attention and learning discipline affected English learning achievement significantly.

Finally the decision of the third hypothesis, Ha was accepted. So, it could be interpreted that there are the effects of parents' attention and learning discipline on the English learning achievement in Junior High Schools at Regional Coordination $3^{\text {rd }}$ in Banjarnegara regency..

According to the regression analysis, the result of the correlation $(\mathrm{R})$ was 0.45 . The correlation $(\mathrm{R})$ value was 0.45 . It meant that there are the strong correlation among parents' attention and learning discipline to the English learning achievement. It is proven by the $\mathrm{R}$ value closing on 1 .

\section{Discussion}

The correlation between Parents' Attention and the English Learning Achievement

The data description of parents' attention from the students as the sample research were classified into four categories: high $16,3 \%$, quite high $68,2 \%$, quite low $14,5 \%$, and low $9 \%$. The majority of students getting parents' attention were quite high. It meant that parents' attention was given to the children in learning English in quite high position related to English learning achievement. This was because the parents' attention played a role in determining the success of students in learning English.

Furthermore, partial correlation analysis shows that the relationship of parents' attention to English learning achievement was 
$\mathrm{r}=0,385$ and $\mathrm{p} \leq 0.05$. Based on the results above, it was described that parents' attention had the relationship significantly to English learning achievement. It meant that higher attention was given to the children. So there was an indication higher English learning achievement.

The parents' attention given to their children can increase the English learning achievement. By involving in English learning, as one way to know what the appropriate attention to their children should be given because the attention to English learning differ with the attention to the other lessons such as help their children in doing the English learning activity. According to Ommrod (2003, P.505) cited from Epstein "students whose parents are involved in school activity have better attendance record, higher achievement, and more positive attitude toward school". It meant that parents had an important role to raise the children English learning achievement. They can choose the appropriate attention by involved in the English learning activity.

The parents as the first persons who understood their children in learning English should have the responsibility in raising the English learning achievement. They do not let their children facing the difficulty in English learning. The form of the responsibility is by giving the attention to their children in learning English because it is their duty to their children is not only at home but also at schoolhad some obligations to the children at home. Therefore, the parents' attention should be given to their children every time and every day. It is in line with Ommord (2003, p.269) cited Secretary of Education Richard Riley " if all parents in America made it their patriotic duty to find an extra thirty minutes to help their children learn more- each and every dayit would revolutionize American Education". This statement is also supported by the survey conducted by the 1990 National Assessment of Educational Progress (NAEP) of fourth eighth and twelfth grades indicated a relationship between literacy and school attendance, outside reading, homework, and television viewing (activities parents can control) (Ommrod, 2003, p.269).

The attention is given to the students as the parents' responsibility on the children education. The education responsibility is focusing and concentrating to their student in learning English. The parents activities in helping their children can be done by involving in the children learning English at home. The involvement also depends on the parents education background. According to Lee and Bowen (2006, p.198) states.

Parents with low levels of education, for example, may be less involved at school because they feel less confident about communicating with school staff owning to lack of knowledge of the school system, a lack of familiarity with educational jargon, ot their own negative educational involvement.

So, the involvement of parents in their children learning will help the children in learning English. The children are motivated to learn English seriously and diligently because they feel save and comfortable at home when their parents give them the serous attention to their English learning. The term of the attention to their children in learning English was to guide or help in finishing the homework. The availability of learning material such as dictionary, English book, and literacy English book helped the children to broad their knowledge of English. Hobby as one of the students' activity should be supported for increasing the ability in learning. Parents also had the important role to overcome the children problem and progress in learning English. Parents talked to the children discussing their problem in learning English. Those supported the children to learn English at home and at school.

The correlation between Learning Discipline and the English Learning Achievement

The data description of learning discipline from the students as the sample research were classified into four categories: 
high $8.3 \%$, quite high $80,7 \%$, and quite low $11 \%$. The majority of students had the quite high learning discipline. It meant that the discipline students in English learning was quite high position gaining the English learning achievement..

Furthermore, partial correlation analysis showed that the influence of learning discipline to English learning achievement was 0.169 and $p \leq 0.05$. Based on the results above, it described that learning discipline had the relationship significantly to English learning achievement. This was because the learning discipline plays a role in determining the success of students in learning English.

Learning is a process of the students getting the knowledge by study. Learning also gets from the experience or instruction. Brown (2000: 7) defined learning "acquiring or getting of knowledge of a subject or skill by study, experience, or instruction." The students get the knowledge or skill by doing the activity regularly and responsibility. The responsibility of the student is learning whether at home or at school.

The students who have the responsibility in learning do the activities related with the learning. Those activities are done correctly and regularly. Supporting this activity, It is needed a rule that can make good climate in English learning. So the starting points of creating good climate of learning is a positive teacher-students and parents-students relationship in which there is a mutual respect and a sense of shared responsibility. A good discipline in learning is from the selfdiscipline. Tan and Yuanshan (1999, p.10) states "discipline is more than keeping order and following rules. In fact, the best kind of discipline is self-discipline which is based on a sense of responsibility, consideration for others and self-respect".

The term of discipline was started from home such as preparing the material before going to school. While, learning the material before the class at home also helped the students to be readiness in learning process in the class. In the school, the students obeyed the school rule such as come to school on time. While, in the classroom the students obeyed the learning rule such as giving attention to their teacher in his/her explanation, writing the material given by teacher. The obedience of the obligation in learning English was also the responsible of parents and teacher. The obligation meant that the students obeyed the rule of learning at home and at school. The home was the place where the students mostly spent more time after school.

The Effects of Parents' Attention and Learning Discipline on English Learning Achievement

The analysis data using Multiple Regression concluded there was the effect parents' attention and learning discipline on English learning achievement. It was shown the determine coefficient was Adjusted $\mathrm{R}^{2}=$ 0.197 and $p \leq 0.05$. In other words, It was interpreted that the variant of English learning achievement of junior high school students in Banjarnegara regency was predicted by parents' attention and learning discipline variable $19,7 \%$. Remaining value $100 \%-20.2$ $\%=79.8 \%$ was decided by other variables not examined in this research.

Parents' attention and learning discipline was proven significantly that both variables effect on the English learning achievement. The data showed that parents' attention and learning discipline were important to English learning achievement.

Meanwhile, the correlation between parents' attention and learning discipline to the English learning achievement is in the strong correlation. It can be seen from the correlation $(\mathrm{R})$ value 0.45 . It meant there are the strong correlation between parents' attention and learning discipline to the English learning achievement because the $\mathrm{R}$ value was close to 1 .

\section{Conclusion And Implication}


Conclusion

The reference to the data analysis and hypothesis test in this research, It can be concluded that parents' attention and learning discipline simultaneously affect on the English learning achievement in Junior High School at Regional Coordination $3^{\text {rd }}$ in Banjarnegara Regency. Parents' attention has the role higher than learning discipline to improve English learning achievement in Junior High School at Regional Coordination $3^{\text {rd }}$ in Banjarnegara Regency.

\section{Recommendations}

English learning achievement as the interpretation of the students who follow the teaching learning process can be developed by building the communication among parents, sechool, and students. The school can give the information of the important of parents, attention and learning disscipline.

The students are suggested to obey the school rules, English learning rule at classroom so it can create the good clime for English learning at school. The students also have a discipline in learning at home. By doing activity after school such as finishing the homework or preparing the school material before going to school. Learning discipline is actually at home or at school to give effect on English learning achievement.

Parents are suggested to give the enough attention to the students learning. Parents can guide and help the children in English learning, preparing the material related to support the children English learning. The other attention giving to the children is the parents fostering the hobby.

The teacher has an important role in English learning achievement. The teacher is expected to help the students in planting learning discipline at school. It's purposed to make a good climate for English learning to gain the good English learning achievement.

School as an education institution organizes the formal education. School should facilitate to the parents about what should and should do to the children in order to increasing the children achievement. The term of cooperation between parents-school is building the communication between parents and school.

\section{Bibliography}

BNSP. (2013). Prosedur Operasional Standar: Penyelenggaraan Ujian Nasioanl Sekolah Menengah Pertama/Madrasah Tsanawiyah, Sekolah Menengah Luar Biasa, Sekolah Menengah Atas/Madrasah Aliyah, Sekolah Menengah Atas Luar Biasa, Sekolah Menengah Kejuruan, Serta Pendidikan Kesetaraan Program Paket A/ULA, Program Paket B/WUSTHA, Program Paket C, dan Program Paket C Kejuruan. Tahun Pelajaran 2012/2013.Cohen. L., et.al. (2005). Research method in education. New York: Routledge Falmer.

Brown, (2007). Teaching by principles: an interactive approach to language pedagogy ( $3^{\text {th }}$ ed.). New York: Pearson Education.

Epstein, L. J., (2009). School, family, and community partnerships ( $3^{\text {rd }}$ ed.). Thousand Oaks: Corwin Press.

Field, A. (2009). Discovering statistics using SPSS: sex, drugs, rock 'n' roll (3 ${ }^{\text {rd }}$ Ed.). Thousand Oaks: SAGE Publication.

Flicker, S.E., \& Hoffman, A.J. (2006). Guiding children's behavior: developmental discipline in the classroom. New York: Teacher College Press.

Hair, et.al, (2006). Multivariate data analysis. ( $6^{\text {th }}$ ed.). Upper Saddle River: Pearson Education. Inc. 
Issac, S. \& Michel, B. (1984). Hand book in research and evaluation. San Diego: EdlTs Publushers.

Lee, S. J. \& Bowen, K. N. (2006). Parent involvement, culture capital, and the achievement gap among elementary school children. American Educational Research Journal. Vol. 43, No. 2, pp. 193-218.

Ommrod, E. J. (2003) Educational psychology: developing learner $\left(4^{\text {th }}\right.$ ed.). Upper Saddle River: Pearson Education.inc.

Savage, V. T. \& Savage, K. M. (2010). Successful classroom management and discipline: teaching self-control and responsibility $\left(3^{\text {rd }}\right.$ ed). Thousand Oaks: SAGE Publication.

Sugihartono, et.al, (2006). Psikologi pendidikan. Yogyakarta: UNY Press. 